УДК $378.147+159.923 .2$

Вікторія Ягоднікова, доктор педагогічних наук, професор кафедри загальнонаукових, соціальних та поведінкових наук Одеського інституту Міжрегіональної Академї управління персоналом

\title{
ТРЕНІНГОВІ ТЕХНОЛОГІЇ У РОЗВИТКУ СОЦІАЛЬНОЇ ЗРІЛОСТІ СТУДЕНТІВ
}

У статті розглянуто різні підходи до визначення поняття соияіальна зрілість, визначеної критерії. соичільна активність, наявність життєвих ичілей, відповідальність, комунікативні уміння. Доведена ефективність застосування тренінгових технологій у педагогічному процесі. Розкрито основний зміст тренінгу з розвитку сочіальної зрілості та представлені результати експериментальної перевірки його ефективності. Достовірними висновками дослідження встановлено позитивний вплив програми тренінгу на особистісне зростання і професійне становлення студентів, щцо сприяє їх розвитку соціальної зрілості.

Ключові слова: соціальна зрілість, студенти, тренінг, тренінгові технології.

תim. 5.

Viktoriya Yahodnikova, Doctor of Sciences (Pedagogy), Professor of the General, Social and Behavioral Sciences Department Odessa Institute, Interregional Academy of Personnel Management

\section{THE TRAINING TECHNOLOGIES IN THE DEVELOPMENT OF STUDENTS SOCIAL MATURITY}

The article deals with the different approaches to the definition of social maturity, the defined criteria: social activity, the existence of life goals, responsibility, communicative skills. The efficiency of application of training technologies in the pedagogical process is proved. The main content of the training of the development of social maturity is revealed and the results of the experimental verification of its effectiveness are presented.

The structured training program contains three blocks: development of social qualities of students, providing effective interactive interaction; gaining experience of social activity and social responsibility; the striving or personal and professional success. Each block of the program is designed for 3 hours of work. The training program, in accordance with the block theme, consists of a set of exercises, role and business games, creative tasks, discussions, mini-lectures, case-method, and project method.

Relevant findings of the study have established the positive impact of the training program on personal growth and the professional development of students, which contributes to their development of social maturity.

The obtained results of the study showed that the developed and tested training promotes social activity of students, development of social qualities, definition and comprehension of life and professional position, acquisition of experience of social interaction, modeling of the future, independence and responsibility. As a result of the training, the communicative and volitional potentials of students are intensified; the motivation of personal and professional growth is actualized.

Keywords: social maturity, students, training, training technology.

П остановка проблеми. Динамічний розвиток інформаційного суспільства, процеси світової глобалізації та інтеграції, трансформації соціально-економічного, суспільно-політичного та духовно-культурного життя держави вимагають активного включення молоді, зокрема студентів, як майбутніх фахівців, у соціальне життя країни. Реалії сьогодення потребують нову генерацію висококваліфікованих молодих спеціалістів 3 інноваційним мисленням і поведінкою, певним соціальним досвідом, здатних до виконання соціальних ролей, до прийняття самостійних і відповідальних рішень, адекватних дій у невизначеної ситуації, швидкої адаптації в мінливих соціальних умовах. Тому вища школа повинна забезпечити студентів інструментарієм щодо життєвої і професійної стратегії розвитку, формуванню соціальних якостей, ціннісної орієнтації, соціально компетентної поведінки, що будуть сприяти реалізації професійних та соціальних функцій фахівців та визначення перспектив розвитку динамічних і кардинальних змін у всіх сферах життєдіяльності українського суспільства. У цьому контексті актуальності набуває проблема пошуків шляхів оптимізації соціального становлення студентів, розвитку соціальної зрілості як умови їхньої продуктивної взаємодії з соціальним середовищем та успішного особистісного і професійного самоствердження і самореалізації. Зважаючи на те, що в сучасній педагогіці найефективнішими формами, методами, технологіями, прийомами, засобами навчання і виховання визнані інтерактивні, вважаємо, що тренінгові технології $\epsilon$ ефективними у розвитку соціальної зрілості студентів. 
Аналіз останніх наукових досліджень і публікацій свідчить, що проблема соціальної зрілості стала предметом дослідження філософів, соціологів, психологів, педагогів. Теоретичні аспекти, сутність, структура соціальної зрілості досліджено в науковому доробку К. АльбухановаСлавської, І. Беха, О. Киричук, О. Михайлова, В. Радула, В. Ядова та ін.

Проблема виховання соціальної зрілості знайшла відображення у працях педагогів С. Вершловського, О. Каменєвої, Л. Канішевької, Б. Кобзар, А. Мельчукової, А. Познякова, Є. Постовойтовата ін.

Особливості застосування тренінгу як активного засобу навчання i виховання досліджували В. Беспалько, Л. Бондарєва, Г. Ковальов, К. Корольова, С. Макшанов, К. Мілютіна, Л. Мороз, С. Сисоєва та ін. Незважаючи на вагомий вклад науковців в розв'язання означеної проблеми, слід зазначити не достатньо вивчені можливості застосування тренінгових технологій у розвитку соціальної зрілості студентів.

Мета статті - розкрити основний зміст тренінгу 3 розвитку соціальної зрілості та експериментально перевірити його ефективність.

Виклад основного матеріалу. Соціальна зрілість, як засвідчив аналіз наукової літератури, науковцями трактується науковцями неоднозначно: як результат самовизначення (Л. Божович, В. Мухіна, В. Сафін), комплекс базових соціальних якостей (О.Каменєва), інтегративна характеристика особистості (О. Киричук, М. Савчин), спрямованість на поведінку в суспільстві, яка передбачає здатність до самостійного i відповідального ухвалення рішень, визначення власного життєвого шляху, прагнення до саморозвиткуі самовдосконалення(С. Вершловський). На думку В. Радула, соціальна зрілість являє собою процес розкриття та розвитку потенційних можливостей особистості та гарантує сформованість таких якостей індивіда, що мають суттєвий вплив на саморегуляцію його поведінки. Розвиток соціальної зрілості як особистісного новоутворення веде до постановки нових завдань, вирішення яких відкриває можливості для нових життєвих виборів особистості, для нових кроків у саморозвиткові та самоздійсненні $[4,18]$.

Пошук форм і засобів розвитку соціальної зрілості, на нашу думку, слід розпочати 3 вивчення основних методів взаємодії як взаємовпливу суб' єктів навчально-виховного процесу, якими володіє сучасна педагогіка.

Останнім часом у працях науковців значна увага приділяється впровадженню активних методів у навчально-виховний процес, серед яких пріоритетним $є$ тренінгові технології. В нашому дослідженні ми спираємося на визначення тренінгу як багатофункціонального методу цілеспрямованих змін психологічних феноменів людини, групи або організації 3 метою гармонізації професійного та особистісного буття людини (С. Макшанов) [3].

А. Галімов досліджуючи можливості соціальнопсихологічного тренінгу щодо комунікативних і емпатійних якостей майбутніх фахівців соціальної сфери визначив особливості тренінгу як технології: груповий процес; активність учасників; мета тренінгового навчання орієнтована на запитання та пошук відповіді, набуття досвіду і допомогу в саморозвитку; принцип “тут і зараз”, позитивна атмосфера заняття, поєднання різних різноманітних стилів подачі матеріалу [1, 42].

Таким чином, сугтєвою перевагою тренінгу $є$ те, що він створює безпечну обстановку і дає можливість вчитися без хвилювання стосовно неприємних наслідків, які можуть виникнути у випадку прийняття неправильного рішення.

Висока ефективність тренінгової технології $\epsilon$ результатом того, що на занятті створюються комфортні умови, цінується позиція й знання кожного учасника, $є$ можливість вчитись виконуючи практичні дії, можна ділитися власним досвідом, а помилки не призводять до негативних наслідків.

На думку О. Керик тренінгові технології забезпечують підвищення рівня соціалізації студентів, що проявляється у здатності до передачі соціальної інформації, задоволеності міжособистісними стосунками, особистіснопрофесіональному самовизначенні, про соціальній активності, розвиненості лідерських якостей і творчих здібностей $[2,139]$.

Зважаючи на те, що тренінг є засобом й шляхом (впорядкованою дію) з метою одержання певного результату в процесі навчально-виховної роботи (О. Падалка) [5], саме він був обраний як засіб розвитку соціальної зрілості студентів.

Аналіз наукового фонду з досліджуваної проблематики й узагальнення практичного досвіду з розвитку соціальної зрілості було розроблено й апробовано тренінгова програма, метою якої $є$ розвиток соціальної зрілості студентів. Основні завдання - розвиток соціальної активності, оволодіння комунікативними вміннями та навичками соціальної взаємодії, визначенні та осмисленні студентами життєвих цілей, власної життєвої і професійної позиції, формуванні позитивного ставлення до життя та професійної діяльності, навичок саморегуляції, 


\section{ТРЕНІНГОВІ ТЕХНОЛОГІЇ У РОЗВИТКУ СОЦІАЛЬНОЇ ЗРІЛОСТІ СТУДЕНТІВ}

виявлення ресурсів подальшого особистісного та професійного зростання, набутті впевненості у собі, цілеспрямованості і відповідальності.

Принципи побудови програми: педагогічне стимулювання соціальних спроб; добровільності, особистісно-діяльнісний підхід, моральне збагачення соціального середовища.

Структурно програма містить три блоки: розвиток соціальних якостей студентів, що забезпечують ефективну інтерактивну взаємодію; набуття досвіду соціальної активності і соціальної відповідальності; прагнення до особистісного і професійного успіху.

Кожний блок програми розрахований на 3 години роботи. Тренінгова програма, відповідно до теми блоку, складається з сукупності вправ, рольових і ділових ігор, творчих завдань, дискусій, міні-лекцій, кейс-методу, методу проектів тощо. Зазначимо, що кожне завдання виконується в малій групі, яка кожен раз утворюється знову. Таким чином, під час участі у тренінгу студенти мають змогу взаємодіяти зі всіма учасниками, набуваючи досвіду встановлювати контакти та швидко знаходити плідні шляхи співпраці.

Зазвичай, заняття блоку містять традиційну структуру тренінгу: вступ, розминка, основна частина, підведення підсумків.

Вступ передбачає налаштування учасників на роботу, вирішення організаційних питань та складається 3 таких кроків: представлення тренера та його помічників; оголошення теми тренінгу; плану-графіку роботи (час проведення, перерви тощо), приймаються Правила роботи, наприклад цінувати час (говорити по черзі, коротко і нечасто, за темою заняття, говорити тільки від свого імені, бути позитивними до себе та інших (Бути +$)$, правило додавання $(Я+$ Ти + Ми), правило добровільної активності, правило конфіденційності, правило правої руки.

Розминка - це вправи та ігри, спрямовані на створення внутрішньої свободи учасників групи, на встановлення контактів з іншими учасниками, активізації уваги і мислення, введення в стан тренування, гри, сприяння зняттю емоційного напруження i хвилювання, встановлення позитивної атмосфери. Ці заходи дозволяють змінити психофізичний стан учасників, долати нерішучість, соромливість, надавати кожному можливість відчувати себе природно й безпечно. Вони сприяють активізації, підвищенню працездатності групи. Під час тренінгів використовуються вправи “Липучки”, “Фігурні побудови”, “Взаємовідносини”, “Ведучий та ведений”, “Веселий м'ячик”.

Основна частина включає міні-лекції, відеопрезентації, дискусії, а також інтерактивні тематичні вправи, ігри, тобто конкретну роботу учасників за темою блоку тренінгу.

Міні-лекції містить стислу інформацію, що розкриває теоретичні засади проблеми, якій присвячений тренінг. Для візуалізації інформації міні-лекції супроводжується відеопрезентаціями, що надає можливості учасникам краще зрозуміти і запам'ятати отриману інформацію.

Інтерактивні тематичні вправи дозволяють використовувати знання, набути досвід, відпрацювати конкретні дії у соціальному середовищі. Основними елементами таких вправ зазвичай $є$ : інструкція, за допомогою якої тренер пояснює завдання і хід вправи; самостійна робота кожного учасника чи спільна робота в малій творчій групі; презентація завдання, спостереження кожного учасника за діями інших, що дозволяє провести обмін думками й результатами; контроль над результатом під керівництвом тренера. Наприкінці вправи підводиться підсумки того, що відбувалося в групі, роз'яснюється, як це повинно бути в реальній практичній діяльності. Слід зазначити, що інтерактивні тематичні вправи підвищують інтерес учасників до визначеної проблеми, сприяють їх активності, створюють позитивну конструктивну робочу атмосферу. Такими вправами відповідно до теми тренінгу є:

- вправи на розвиток організаторських i комунікативних якостей - “Якості для ефективного спілкування”, “Портрет групи”, "Геометрична композиція".

- вправи на набуття досвіду соціальної активності і соціальної відповідальності “Кожен 3 нас особистість”, “Щиро про себе та інших”, “Шлях знаходження рішення”, “Проблеми коло нас”, “Безлюдний острів”, полювання “Всякі різнощі”, захист соціальних проектів.

- вправи на розвиток соціальних якостей (упевненість у собі, цілеспрямованість, позитивне ставлення до себе й оточення, самостійність, відповідальність) - “Якості, що допомагають та заважають розвитку соціальної зрілості”, “Моя яблунька", “На шляху до успіху”, “Мої якості успішності”, колаж “Шлях, який обираю Я!”, презентації свого успіху.

Для формування та розвитку умінь і навичок, набуття практичного досвіду використовуються ігри. Зазвичай, ігри проводяться за етапами, які передбачають підготовку до гри (ознайомлення 3 темою і правилами гри, ознайомлення зі сценарієм гри, визначення ігрових завдань, ролей, орієнтовних шляхів розв'язання проблеми), проведення гри та іiі обговорення. 


\section{ТРЕНІНГОВІ ТЕХНОЛОГІЇ У РОЗВИТКУ СОЦІАЛЬНОЇ ЗРІЛОСТІ СТУДЕНТІВ}

Так, для опрацювання навичок ефективного спілкування, спільної діяльності, умінь інтерактивної взаємодії пропонується імітаційномоделююча гра “Каламбрія”. За допомогою цієї гри учасники мають змогу дослідити свою природну поведінку, вийти за межі звичних поведінкових стереотипів і шаблонів, засвоїти позиції суб'єктсуб'єктної взаємодії, відпрацювати дії, необхідні у невизначених, нетипових ситуаціях.

Імітаційні ігри, чи симуляції, відображають явища професійної реальності, дозволяють відтворювати реальні ділові ситуації, події (кейси). Застосовуються кейси “Вольові зусилля та досягнення мети”. Зазначимо, що кейси складаються самими учасниками, містять ситуації з їх досвіду, тому вони різні за рівнем складності й узагальнення інформації.

У ході проведення тренінгів організовуються дискусії, елементами яких є спілкування-діалог учасників; упорядкований обмін думками; висловлювання, вислуховування, використання невербальних виразних засобів; цільова спрямованість обговорення. Тема дискусії сприяє активному залученню учасників до обговорення й обирається відповідно до завдань кожного тренінгу. Такими темами для обговорення $є$ "Моя життєва і професійна позиція”, “Якщо не я, то хто?” та інші. Під час дискусій відбувається обмін інформацією, вільний обмін думками. Зауважимо, що результати дискусії не передбачають обов'язкового пошуку єдиної позиції. Різні підходи до одного і того самого предмета або явища, розбіжність поглядів формують повагу до іншої думки, комунікативну культуру, розширювали межі сприйняття, долались бар'єри спілкування, набувався досвід спільної діяльності.

Кожне заняття блокузакінчується підведенням підсумків - вправою, грою чи дискусією, спрямованою на закріплення досвіду, створення рефлексії, виявлення очікуваних результатів, 3'ясування, наскільки досягнута мета заняття. Наприклад, у цієї частині тренінгу учасникам пропонується вправа “Великі ідеї приходять тоді, коли світ потребує їх”, мета якої полягає у визначенні кожним учасником $5-7$ ідей, що виникли у них під час тренінгу і які можна впровадити в практику. Таким чином, зазначена вправа спрямована на закріплення і узагальнення отриманих знань, умінь і досвіду, підведення підсумків роботи та отримання зворотного зв'язку.

Експериментальна робота $з$ впровадження тренінгу з розвитку соціальної зрілості відбувалась зі студентами спеціальності “Практична психологія" (ЕГ) та спеціальності “Менеджмент”
(КГ) на базі Одеського інституту Міжрегіональної академії управління персоналом.

Оцінка результатів ефективності проведеного тренінгу здійснювалась на основі визначених нами показників соціальної зрілості: соціальна активність, наявність життєвих цілей, відповідальність, комунікативні уміння. Діагностичним інструментарієм були обрані самооцінка результатів тренінгу самими учасниками, опитувальник Ш. Шварца для вивчення ціннісної сфери особистості, “Тест комунікативних умінь” Л. Міхельсона (переклад і адаптація Ю. Гільбуха).

За результатами опитування $84 \%$ учасників вказали, що у них відбулися позитивні зміни. Зокрема, 72\% - вказали, що вони усвідомили для себе необхідність індивідуального і професійного зростання, 52\% - набули навички планування професійної кар'єри, 40\% - набули досвід створення стратегії самореалізації у обраної професії, 54\% - відзначили більш глибоке пізнання себе та розуміння інших, $65 \%$ упевненість в собі, 30\% набули умінь чітко і вільно висловлювати свої думки і вступати у взаємодію 3 іншими, 63\% - скорегували свою самооцінку.

Одержані результати дослідження засвідчили, що у КГ відмінності незначні чи майже не відбулись, що можливе визначити як звичайне в умовах традиційного навчально-виховного процесу. Найбільші зміни відбулися в ЕК після проведення тренінгу. Так, відмінності між середніми значеннями виділяються за показником соціальна активність і (ЕГ - до експерименту $33,2 \%$ та після 58,4\%; КГ - 34\% та $-34,5 \%$ відповідно) та комунікативні уміння (ЕГ до $40,5 \%$ та після $64,2 \%$; КГ 42,6\% та $43,3 \%$; відповідно). Відмінності відбулись в ЕГ за показником “відповідальність” -до - 18,2\%, після 22, 7\%; у КГ відмінності майже не відбулись - до - 17,3\%, після 17,6\%. За показником “наявність життєвих цілей” уЕГ до експерименту - 8\%, після - 10,6\%; у КГ відмінності не відбулись - 7,4\%.

Достовірні висновки про ефективність тренінгу було зроблено завдяки порівнянню показників соціальної зрілості. Значущість відмінностей середніх значень показників було визначено за допомогою t-критерію Стюдента для залежних вибірок. Значні відмінності виявились за всіма показниками соціальної зрілості на рівнях значущості $p \leq 0,05$ та $p \leq 0,01$.

Отже, достовірними висновками дослідження встановлено позитивний вплив програми тренінгу та особистісне зростання і професійне становлення студентів, що сприяє їх розвитку соціальної зрілості. 


\section{ТРЕНІНГОВІ ТЕХНОЛОГІЇ У РОЗВИТКУ СОЦААЛНОЇ ЗРІЛОСТІ СТУДЕНТІВ}

Висновок. Одержані результати дослідження засвідчили, що розроблений і апробований під час формувального експерименту тренінг сприяє соціальної активності студентів, розвитку соціальних якостей, визначенню і осмисленню життєвої і професійної позиції, набуттю досвіду соціальної взаємодії, моделювання майбутнього, самостійності і відповідальності. У результаті тренінгу активізуються комунікативні і вольові потенціали студентів, актуалізується мотивація до особистісного і професійного зростання.

Подальші розвідки вбачаємо у визначенні педагогічних умов розвитку соціальної зрілості студентів, їх обгрунтуванні і експериментальній перевірці.

\section{ЛІТЕРАТУРА}

1. Галімов А. В. Дослідження можливостей сочіально-психологічного тренінгу щзодо формування комунікативних та емпатійних якостей майбутніх фахівців сочіальної сфери / A. В. Галімов // Збірник наукових працьь Хмельницького інституту сочіальних технологій Університету “Україна". - 2009. - № 1. - C. 4247.

2. Керик О. Використання тренінгових технологій у професійній підготовиі фахівців сочіальної сфери / О. Керик // Молодь і ринок. 2015. - № 2(121). - C. 136-140.

3. Макшанов С.И. Психология тренинга: Теория. Методология. Практика: Монография. / С. И. Макшанов. - СПб.: Образование, 1997. $238 \mathrm{c}$.

4. Радул В. В. Соціальна зрілість як вершина акмеологічного розвиткуособистості /В. В. Радул // Рідна школа. - 2011. - № 3. - С. 15-20.
5. Сучасні педагогічні технологї: навчальний посібник/А. С. Нісімчук, О. С. Падалка, О. Т. Шпак. - К.: Вид. иентр “Просвіта", Пошук.-вид. агентство “Книга пам'яті Украӥни”, 2000. - 368 с.

\section{REFERENCES}

1. Halimov, A. V. (2009). Doslidzhennia mozhlyvostei sotsialno-psykholohichnoho treninhu shchodo formuvannia komunikatyvnykh ta empatiinykh yakostei maibutnikh fakhivtsiv sotsialnoi sfery [Investigation of the possibilities of social-psychological training on the formation of communicative and empathic qualities of future specialists in the social sphere]. Collection of scientific works of the Khmelnytsky Institute of Social Technologies of the University of Ukraine. Khmelnytsky, no.1, pp. 42-47. [in Ukrainian].

2. Keryk, O. (2015). Vykorystannia treninhovykh tekhnolohii u profesiinii pidhotovtsi fakhivtsiv sotsialnoi sfery [Use of training technologies in the training of specialists in the social sphere].Youth and market. Drohobych: no.2 (121), pp. 136-140. [in Ukrainian].

3. Makshanov, S.Y. (1997) Psykholohyia trenynha: Teoryia. Metodolohyia. Praktyka [Psychology of training: Theory. Methodology. Practice]. St. Petersburg: Obrazovanye, 238 p. [in Russian].

4. Radul, V. V. (2011). Sotsialna zrilist yak vershyna akmeolohichnoho rozvytku osobystosti [Social maturity as the apex of acmeological development of personality]. Native school. Kyiv, no.3, pp. 15-20. [in Ukrainian].

5. Nisimchuk, A. S. Padalka, O. S. \& Shpak, O. T. (2000). Suchasni pedahohichni tekhnolohii [Modern pedagogical technologies]. Kyiv, Vyd. tsentr "Prosvita", 368 p. [in Ukrainian].

Стаття надійшла до редакції 22.01.2018

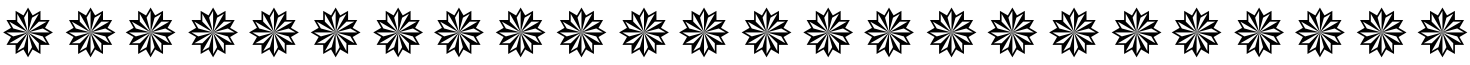 "Справжній педагогічній творчості властиві риси дослідження, творчого узагальнення своєї праці".}

"Немає людей, більи допитливих, невагомих, більи одержимих думқами про твориість, якуиителі”.

Василь Сухомлинський український педагог, публіцист, письменник

“Мудра людина не робитиме іншим того, чого вона не бажає, щоб зробили ій”.

Конфбучій давньокитайський білософб

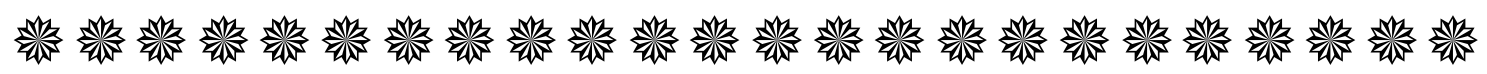

